Review

\title{
The interface of COVID-19, diabetes, and depression
}

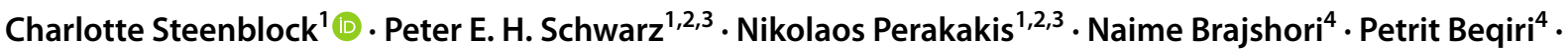 \\ Stefan R. Bornstein ${ }^{1,2,3,5,6}$
}

Received: 15 December 2021 / Accepted: 27 January 2022

Published online: 01 March 2022

(c) The Author(s) 2022 OPEN

\begin{abstract}
Comorbid diabetes with depression is a challenging and often under-recognized clinical problem. During the current COVID-19 pandemic, a communicable disease is thriving on the increasing incidences of these non-communicable diseases. These three different health problems are bidirectionally connected forming a vicious cycle. Firstly, depressed individuals show a higher risk of developing diabetes and patients with diabetes have a higher risk of developing symptoms of depression. Secondly, patients with diabetes have a higher risk of developing severe COVID-19 as well as of experiencing breakthrough infections. Thirdly, in both patients with type 2 diabetes and in COVID-19 survivors the prevalence of depression seems to be increased. Fourthly, lockdown and quarantine measurements during the COVID-19 pandemic has led to an increase in depression. Therefore, it is of importance to increase the awareness of this interface between depression, diabetes and COVID-19. Finally, as symptoms of post-COVID, diabetes and depression may be overlapping, there is a need for educating skilled personnel in the management of these comorbidities.
\end{abstract}

\section{Introduction}

Infectious and metabolic diseases, such as diabetes, are major health problems worldwide [1]. Likewise, the high prevalence of depression is considered a global health burden [2]. Moreover, comorbid diabetes and depression is a challenging and often under-recognized clinical problem $[3,4]$.

In the last decades, medical advances, access to better health care (e.g. vaccination) and improved sanitation have reduced the overall mortality and morbidity due to infectious diseases, in particular for lower respiratory tract infections and diarrheal disease [5]. Nevertheless, mortality and morbidity as a result of neglected tropical diseases, HIV infection, tuberculosis and malaria remain high in low-income countries [5]. Furthermore, the number of deaths due to new and re-emerging infections in addition to seasonal and endemic infections have remained relatively constant in the twentyfirst century [5]. In addition, in the last decades, the spreading-speed of infectious diseases has escalated unprecedently due to technological, demographic and climatic changes: people travel more, more people live in urban than in rural areas and the population numbers are continuously increasing [5]. A phenomenon that unfortunately has been further observed during the current COVID-19 pandemic.

$\triangle$ Charlotte Steenblock, charlotte.steenblock@uniklinikum-dresden.de | ${ }^{1}$ Department of Internal Medicine III, University Hospital Carl Gustav Carus, Technische Universität Dresden, Fetscherstrasse 74, 01307 Dresden, Germany. ${ }^{2}$ Paul Langerhans Institute Dresden (PLID), Helmholtz Center Munich, University Hospital and Faculty of Medicine Carl Gustav Carus, TU Dresden, Dresden, Germany. ${ }^{3}$ German Center for Diabetes Research (DZD E.V.), Neuherberg, Germany. ${ }^{4}$ Research Unit, Heimerer College, Prishtina, Republic of Kosovo. ${ }^{5}$ Department of Endocrinology, Diabetology and Clinical Nutrition, University Hospital Zurich, Zurich, Switzerland. ${ }^{6}$ Department of Diabetes, School of Life Course Science and Medicine, Kings College London, London, UK. 
Harmful interactions between infectious and metabolic diseases that involve the immune system and multiple other organ systems (e.g. pancreas, adrenal glands, adipose tissue, liver, and gut) are present [6]. For example, development of acute diabetes after viral infections, such as Mumps, Coxsackie B3 and B4, Rubella, and Influenza B, has been reported [7]. In this instance, insulin-producing beta-cells are damaged due to the direct infection without autoimmunity [7, 8]. An alternative mechanism might be due to chronic, repeated viral exposure. This mechanism includes molecular mimicry, where viral epitope sequences bear resemblance to beta-cell antigens e.g. viral peptides and insulin. Thereby, they can potentially trigger a cross-reactive autoimmune response $[9,10]$. These interactions are bidirectional and have a major impact on metabolic or infectious disease development, severity, duration, response to treatment and consequently on quality of life and mortality. The overwhelming dimension of this problem has become evident in the current COVID-19 pandemic, in which we have witnessed a communicable viral pandemic with the existing non-communicable pandemic of metabolic diseases affecting a significant percentage of the world population [11].

On top of this, the number of people diagnosed with major depression is steadily increasing. In 2019, it was found that globally depression caused 46.9 million Disability Adjusted Life Years (DALYs) [1]. Moreover, the majority of depression cases remain undiagnosed or untreated, a problem that is more severe in low- and middle-income countries [12].

A number of symptoms connected to post-COVID, diabetes and depression, such as fatigue and increased levels of cytokines, are similar (Fig. 1). In the current narrative review, we will discuss what is already known about the interface between COVID-19, diabetes and depression and discuss the challenges for health personal to identify the symptoms and to prevent long-term consequences. First, we describe the interaction between diabetes and depression, then we focus on patients with diabetes and the impact of COVID-19 on this group of patients. Afterwards, we discuss how COVID-19 can lead to depression and at the end, we highlight the interaction between diabetes, depression and COVID-19. In our conclusion, we discuss how important it is to be aware of this vicious cycle and to educate skilled personnel.

For preparation of the manuscript, we searched PubMed and Google Scholar for articles published up to January 20, 2022. Search items included "COVID-19", "post-COVID", "long COVID", "SARS-CoV-2", "diabetes", "hyperglycaemia", "hyperglycemia", "insulin", and "depression". The reference list of original articles, narrative reviews, clinical guidelines, position statements, systematic reviews, and meta-analyses was screened for applicable publications. The final

Fig. 1 Interface of COVID-19, diabetes and depression. Symptoms of these three health problems are partly overlapping indicating the importance of educating skilled personnel to detect and diagnose these symptoms in order to employ the right treatment

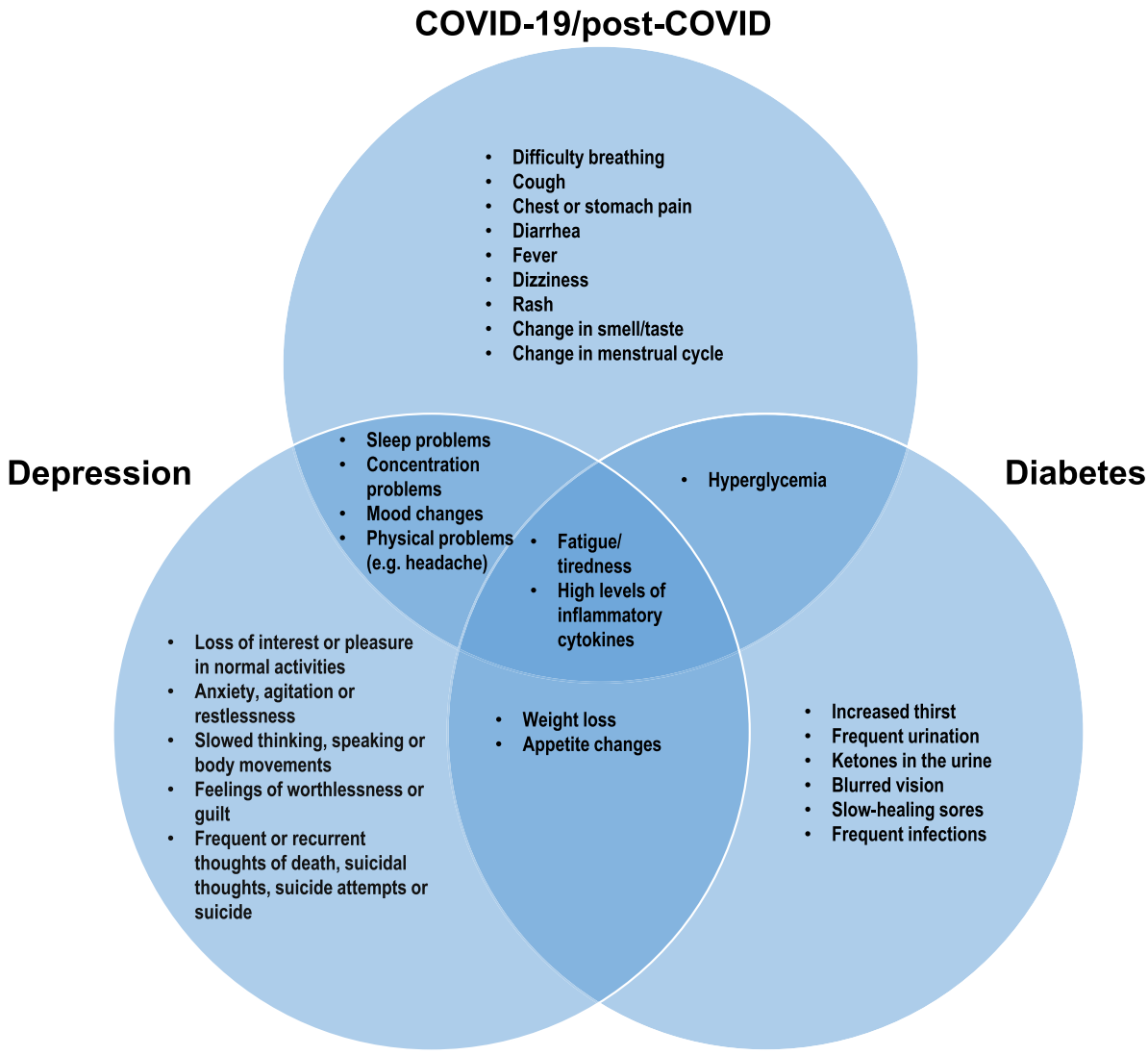


reference list was selected based on relevance to the topic of this Review with preference given to the most recent relevant publications.

\section{Diabetes and depression}

In 2019 , the global diabetes prevalence was estimated to be $9.3 \%$ (463 million people), rising to $10.2 \%$ (578 million) by 2030 and $10.9 \%$ (700 million) by 2045 . The prevalence was higher in urban (10.8\%) than in rural (7.2\%) areas. Furthermore, the frequency was much higher in high-income (10.4\%) than in low-income countries (4.0\%) [13].

Depression comprises a number of emotional, cognitive, and behavioural or somatic symptoms (Fig. 1) [14]. Depression has a direct or indirect relation with a number of diseases including Alzheimer's disease, stroke, epilepsy, diabetes, cardiovascular disease and cancer [15], and the prevalence of depression is significantly higher in individuals suffering from a chronic disease than in those without [14].

Diabetes is associated with an increased risk of depression [16-19]. At the same time, people with depression have a more than $30 \%$ higher risk of developing diabetes than people without depression [20,21]. The underlying pathophysiological mechanisms behind this bidirectional relationship between diabetes and depression are not fully elucidated but inflammatory mechanisms and insulin resistance seem to play an important role [4]. Both diabetes and depression are associated with a chronic state of systemic low-grade inflammation, and a recent meta-analysis demonstrated that the blood concentrations of C-reactive protein and interleukin-6 (IL-6) were higher in people with type 2 diabetes and comorbid depression than in patients with type 2 diabetes but without depression [22]. On the other hand, the peripheral blood concentration of brain derived neurotrophic factor (BDNF) was lower among the patients with comorbid diabetes and depression [22].

Another shared manifestation of diabetes and depression is the dysregulation of the hypothalamic-pituitary-adrenal cortex (HPA) [23]. This pathway is important under stress and regulate immune function, glucose metabolism and sleep, which are indicators altered in both diseases (Fig. 1) [24]. Under stress, when the HPA axis is activated, corticotropin-releasing hormone (CRH) and arginine vasopressin (AVP) are secreted from the paraventricular nucleus of the hypothalamus. CRH and AVP stimulate the anterior pituitary to secrete adrenocorticotropic hormone (ACTH), and via the bloodstream, ACTH leads to the production of glucocorticoids and mineralocorticoids in the adrenal cortex. The cortisol secreted from the adrenal cortex will subsequently increase blood glucose levels by stimulating gluconeogenesis in the liver and by decreasing glucose uptake in muscle and white adipose tissue, thus antagonizing the effects of insulin on glucose homeostasis. This may further aggravate insulin resistance, increase hunger and lead to weight gain and hyperglycemia [25]. During acute stress, this response is crucial for survival, whereas chronic stress, as in depression, can have harmful effects. Eventually, long-term chronical activation of the HPA axis with elevated cortisol levels may lead to cortisol dysregulation and altered feedback control mechanisms. These changes have been associated with type 2 diabetes and depression [26, 27]. Metabolic stress, as often observed in depression, may also lead to activation of the HPA axis as we have recently observed in mice, where high-fat-diet leads to a hypertrophy of the adrenal gland and hyperactivation of the HPA axis [28].

The co-occurrence of diabetes and depression has not only direct but also indirect consequences on human health due to its impact on patient compliance and self-motivation. Specifically, depression substantially impairs the quality of life in patients with diabetes and more intensive support for diabetes management is required as selfmanagement becomes more challenging [29]. Motivating and convincing patients with diabetes to change lifestyle and adhere to treatment is often already a demanding task. If these patients suffer additionally from depression, it becomes even more complicated.

Diabetic complications, insulin use and educational status have been identified as risk factors for co-morbid depression in patients with type 2 diabetes, whereas regular exercising, gender, marital status and current social status were demonstrated to be protective factors [30]. Furthermore, age is a common risk factor for both diabetes and depression [31]. Thereby women, people with a low educational level and people living in rural areas are at a higher risk, whereas being married and doing regular exercise protect from developing comorbid depression in patients with type 2 diabetes $[17,30]$. Thus, with the increasing life expectations, diabetes and depression represent a serious burden on the medical care systems. Therefore, it is important to promote screening activities and introduce targeted and personalized treatment for depression in order to reduce the risk of poor short- and long-term outcomes of diabetes [17]. 


\section{COVID-19, post-COVID and diabetes}

Diabetes and other metabolic diseases increase the risk of developing severe COVID-19 [11]. In patients with diabetes, impaired insulin signalling might lead to chronic subclinical low-grade inflammation via activation of AP-1 and NF-KB leading to a decrease in anti-inflammatory cytokines and to an increase in the pro-inflammatory cytokines TNF- $\alpha$, IL- 6 and IL-1 $\beta$. These cytokines inhibit insulin signalling [32], thereby boosting insulin resistance [33]. In severe COVID-19, the inflammatory response to SARS-CoV-2 infection can further promote insulin resistance and endothelial dysfunction [11].

Patients with diabetes do not only have a higher risk of developing severe COVID-19, they are also more prone to serious long-term consequences [34,35], as COVID-19 may lead to an aggravation of underlying metabolic diseases and to new-onset-diabetes [36]. New-onset hyperglycaemia, ketoacidosis, diabetes and severe metabolic complications of pre-existing diabetes were repeatedly observed in patients with COVID-19 [37-43]. Patients with abnormalities in their blood glucose levels associated to COVID-19 had increased markers of inflammation and organs' injury and poorer clinical outcome compared to those with normoglycemia [44]. In the pancreas, a direct infection with SARS-CoV-2 of the islets has been shown in several studies [45-47], which, as we have demonstrated, might lead to islet damage and necroptosis [46]. Even in utero, we observed viral infiltration of several organs including the pancreas [48].

In relation to diabetes, long-term consequences of COVID-19 designated as "post-COVID", "long COVID" syndromes [49] or post-acute sequelae of COVID-19 [50], have been observed in a number of studies. One study investigating COVID-19 patients 1 year after recovery and hospital discharge, showed that $\sim 1 \%$ of these patients developed newonset diabetes and in $\sim 10 \%$ of the patients, a worsening in glycaemic control was documented [51]. One Italian study showed that glycaemic abnormalities could be detected at least 2 months after recovery from COVID-19 [41], whereas another study recently showed that the prevalence of dysglycaemia reverted to pre-admission frequencies in most recovered patients [44].

Currently, the number of breakthrough infections with SARS-CoV-2 despite full vaccination are increasing. These patients that are infected even though they are fully vaccinated mostly experience mild symptoms. However, the vaccinated patients that do develop severe symptoms of COVID-19 are often elderly and frequently they suffer of comorbidities such as hypertension, diabetes, congestive heart failure and chronic kidney disease [52] indicating the importance of a booster vaccination especially for these patient groups.

\section{COVID-19 and depression}

The COVID-19 pandemic seriously affects mental health. During a pandemic, the number of people whose mental health is affected actually tends to be higher than the number of people affected by the infection [53]. Prolonged exposure to stressors, such as those experienced through social isolation, concern of being infected, and loss of relatives or friends, increases the risk of developing major depression, anxiety and post-traumatic stress disorders [24]. As mentioned above, this is due to the excessive or chronic activation of the HPA axis, which also leads to a disrupted feedback loop [54].

Several studies are currently emerging showing that social loneliness during COVID-19 lockdowns has had a negative influence on the development of mental diseases in all age groups. Across the world, childhood obesity increased during the pandemic. This was due to changes in the daily routine such as a reduction in physical activity and negative changes in the eating habits during lockdown. This also had a negative impact on psychological wellbeing [55-57]. In adolescents, COVID-19 has dramatically altered the number of social contacts by limiting in-person interactions. Thus, it was shown that particularly girls and individuals with a depressive disorder are at an increased risk of suffering from pandemic-associated psychological distress [58]. A similar pattern was observed with students (18-29 years) in Columbia after social isolation in the COVID-19 pandemic, where women exhibited a higher risk of developing depression symptoms than men [59]. Furthermore, childless people and individuals with low income were more likely to display symptoms of depression [59]. Another study among university students in Germany showed that during the pandemic (June 2020), a small increase in depression was observed, whereas anxiety and somatic complaints did not change significantly compared to before the pandemic (June-August 2019) [60]. A meta-analysis 
revealed that in adults there was a significant relationship between quarantine and mental health during the COVID19 pandemic with the longer the quarantine time, the higher the anxiety, depression and stress levels [61]. Between countries, no differences were observed [61] further pointing out that this is truly a global problem. A study with individuals aged 70 and older showed that in this age group lockdown led to a significant worsening of perceived stress, well-being, depressive symptoms, mood disturbance and memory. On the other hand, significant improvements in self-reported physical health symptoms, social interaction, time spent engaging in physical activity and certain aspects of relationship quality were demonstrated [62]. Follow-up showed that well-being, depression and mood were still negatively affected post-lockdown [62].

Mental health problems that manifested during the pandemic were predominantly associated with current loneliness and pre-pandemic distress [60]. A recent study among health care providers in Kosovo showed that interventions to minimize COVID-19-related mental health consequences by transforming experienced trauma into something positive by improving the coping skills could be highly beneficial in pandemic response work [63]. Overall, these studies underline the importance of adequate mental health care options during quarantine and lockdown. Recent results suggest telehealth to be a feasible care alternative as no significant differences were observed between in-person and telehealth groups in depressive symptom reduction [64].

Growing data indicate that SARS-CoV-2 can directly infiltrate the central nervous system and peripheral nervous system causing multiple neurological diseases. Increased incidences of psychiatric disorders have been observed during and after an infection with SARS-CoV-2 [65]. Most of these patients displayed high levels of pro-inflammatory cytokines [66]. However, a recent systematic review indicates that long-term mental effects from direct COVID-19 infection are associated with no or mild symptoms [67]. Studies exhibiting long-term prevalence of anxiety, depression, PTSD, and sleep disturbances were comparable to the levels observed in the general population [67].

\section{Interface between COVID-19, diabetes and depression}

During the COVID-19 pandemic, we have observed that patients with diabetes have a significantly higher risk of contracting COVID-19 associated with an increased morbidity and mortality [11,34]. The modulating factor for patient's mortality seems to be insulin resistance especially in patients with obesity and type 2 diabetes [11]. Surviving COVID-19, a growing number of patients contract post-COVID-associated fatigue-syndrome [68]. The symptoms of fatigue-syndrome are very similar to depressive symptoms especially in patients with type 2 diabetes (Fig. 1). This vicious circle between diabetes, COVID-19, and depression might be associated with increased mortality (Fig. 2).

Health care avoidance during the COVID-19 pandemic has especially been observed in certain population groups. A population-based cross-sectional study in the Netherlands showed that one in five individuals avoided healthcare during lockdown in the COVID-19 pandemic, often for potentially urgent symptoms. Healthcare avoidance was strongly associated with female sex, fragile self-appreciated health, and high levels of depression and anxiety [69].

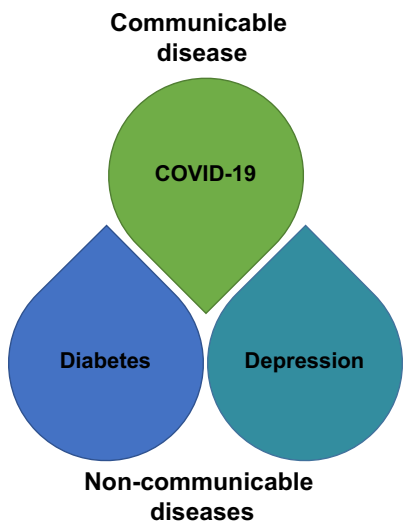

Fig. 2 COVID-19, diabetes and depression form a vicious cycle. On one hand, diabetes increase the risk of severe COVID-19. On the other hand, COVID-19 may lead to new-onset diabetes or worsening of already existing metabolic disorders. On top of this, depressed individuals show a higher risk of developing diabetes and patients with diabetes have a higher risk of developing symptoms of depression. Furthermore, in patients with type 2 diabetes and in COVID-19 survivors the prevalence of depression is increased. Finally yet importantly, lockdown and quarantine measurements during the COVID-19 pandemic has led to an increase in depression 
These results further emphasize the need for targeted public education urging these vulnerable patient groups to timely seek medical care for their symptoms to mitigate major health consequences.

A number of studies have recently focused on individuals with diabetes and the development of diabetes-related emotional distress and/or depression [70-74]. In a German study, it was shown that in patients with diabetes, the initial COVID-19 outbreak had a negative impact on the mental health status in these patients [73]. A similar conclusion was reached in a Brazilian study, where a high degree of psychological distress amongst patients with diabetes was reported [70]. The same working group showed an increase in suicidal thoughts in patients with diabetes 1 year after the COVID-1 outbreak [71]. A study from Saudi Arabia, showed no difference between the prevalence of depression and anxiety symptoms during the COVID-19 outbreak in people with or without diabetes [72]. However, certain subgroups of patients with diabetes showed a higher prevalence than people without diabetes. These subgroups included people who experienced canceling of their diabetes visit by the clinic, or patients that had no method of telecommunication with their health care providers. Furthermore, patients, which in addition to their diagnosis of diabetes, had $\mathrm{HbA} 1 \mathrm{C}$ of $\geq 10 \%$, were women, employees (in particular health care providers), students, unmarried individuals, and those with lower income were more likely to report depression and/or anxiety symptoms [72].

These results indicate the importance of developing strategies to mitigate the negative effects on mental health in especially patients with diabetes during the COVID-19 pandemic. One possibility would be to use telecommunication, which has been shown to have the potential to reduce diabetes-related emotional distress [75]. Thereby, the pandemic has presented people with diabetes and their healthcare providers with an opportunity to innovate and use digitalised care for home support [76].

After acute catastrophes such as a terror attack or a big fire, psychological assistance task forces for victims and their families are usually quickly organized [53]. However, during a pandemic, it is common for health professionals, scientists and managers first to focus on the pathogen and the biological risk in order to better understand the pathophysiological mechanisms involved and to propose measures for preventing, containing and treating the disease. In such situations, the psychological and psychiatric implications secondary to the phenomenon tend to be underestimated or even neglected. Thereby, an unnecessary burden of associated diseases might arise [77, 78].

In the light of the corona pandemic with a higher morbidity and mortality for those patients with diabetes and the growing presence of post-COVID and fatigue-syndrome, the early diagnosis of diabetes-associated depression and the effective management of fatigue-syndromes has become an urgent need. The presence of skilled personnel able to identify early signs of metabolic and/or psychological derangement may prove to be especially useful for preventing long-term complications and fatigue syndrome by facilitating the early initiation of multimodal treatment interventions.

For the future, this requires investment into education of medical personnel including nurses and the whole care team. Training nurses to identify early signs of high-risk medical conditions but also indicators of post-COVID symptoms such as fatigue may become an integral part of the medical care team.

The positive relationship between physical exercise, diabetes and mental health is well-established, but during the COVID-19 pandemic, with various restrictions, the space and facilities for physical exercise are limited. A recent review emphasizes how important it is to perform physical exercise anyway [79]. Especially, supervised physical exercises during COVID-19 were shown to be conducive to enhancing happiness and improving mental health. Furthermore, physical exercise reduced people's anxiety, sadness and depression during the COVID-19 pandemic dependent on the intensity and frequency of physical exercise [79].

\section{Conclusion}

Non-communicable diseases are a global challenge, accounting for $71 \%$ of all deaths worldwide [80]. The spread of COVID-19 and past huge disasters have affected the prevention and treatment of these diseases and require urgent action. Especially, the non-communicable diseases, depression and diabetes, are huge problems as these are directly or indirectly worsened either due to the actual infection or due to social limitations during lockdown or quarantine. A limitation of the current narrative review is that specific mechanisms explaining these correlations are not fully understood yet $[4,81,82]$. Still, symptoms of post-COVID, diabetes and depression are partly similar (Fig. 1) making it important with skilled personnel to detect and diagnose these symptoms in order to employ the right treatment. 
Authors' contributions CS and PEHS wrote the initial draft. Remaining authors wrote smaller sections of the review. CS prepared the figures. All authors reviewed successive drafts of the Review. All authors read and approved the final manuscript.

Funding Open Access funding enabled and organized by Projekt DEAL. The work of CS and SRB is partly supported by grants from the Deutsche Forschungsgemeinschaft (DFG, German Research foundation) Project No. 314061271 and Project No. 288034826.

Data availability Not applicable.

Code availability Not applicable.

\section{Declarations}

Competing interests The authors declare no competing interests.

Open Access This article is licensed under a Creative Commons Attribution 4.0 International License, which permits use, sharing, adaptation, distribution and reproduction in any medium or format, as long as you give appropriate credit to the original author(s) and the source, provide a link to the Creative Commons licence, and indicate if changes were made. The images or other third party material in this article are included in the article's Creative Commons licence, unless indicated otherwise in a credit line to the material. If material is not included in the article's Creative Commons licence and your intended use is not permitted by statutory regulation or exceeds the permitted use, you will need to obtain permission directly from the copyright holder. To view a copy of this licence, visit http://creativecommons.org/licenses/by/4.0/.

\section{References}

1. Diseases GBD, Injuries C. Global burden of 369 diseases and injuries in 204 countries and territories, 1990-2019: a systematic analysis for the global burden of disease study 2019. Lancet. 2020;396:1204-22. https://doi.org/10.1016/S0140-6736(20)30925-9.

2. Mekonen T, Chan GCK, Connor JP, Hides L, Leung J. Estimating the global treatment rates for depression: a systematic review and metaanalysis. J Affect Disord. 2021;295:1234-42. https://doi.org/10.1016/j.jad.2021.09.038.

3. Herrera PA, Campos-Romero S, Szabo W, Martinez P, Guajardo V, Rojas G. Understanding the relationship between depression and chronic diseases such as diabetes and hypertension: a grounded theory study. Int J Environ Res Public Health. 2021. https://doi.org/10.3390/ijerp h182212130.

4. Holt RI, de Groot M, Golden SH. Diabetes and depression. Curr Diabetes Rep. 2014;14:491. https://doi.org/10.1007/s11892-014-0491-3.

5. Baker RE, Mahmud AS, Miller IF, Rajeev M, Rasambainarivo F, Rice BL, Takahashi S, Tatem AJ, Wagner CE, Wang LF, Wesolowski A, Metcalf CJE. Infectious disease in an era of global change. Nat Rev Microbiol. 2021. https://doi.org/10.1038/s41579-021-00639-z.

6. Quinn LM, Wong FS, Narendran P. Environmental determinants of type 1 diabetes: from association to proving causality. Front Immunol. 2021. https://doi.org/10.3389/fimmu.2021.737964.

7. Imagawa A, Hanafusa T, Miyagawa J, Matsuzawa Y. A novel subtype of type 1 diabetes mellitus characterized by a rapid onset and an absence of diabetes-related antibodies. Osaka IDDM study group. N Engl J Med. 2000;342:301-7. https://doi.org/10.1056/NEJM200002 033420501.

8. Boddu SK, Aurangabadkar G, Kuchay MS. New onset diabetes, type 1 diabetes and COVID-19. Diabetes Metab Syndr. 2020;14:2211-7. https://doi.org/10.1016/j.dsx.2020.11.012.

9. Huang Q, Kahn CR, Altindis E. Viral hormones: expanding dimensions in endocrinology. Endocrinology. 2019;160:2165-79. https://doi. org/10.1210/en.2019-00271.

10. Rodriguez-Calvo T. Enterovirus infection and type 1 diabetes: unraveling the crime scene. Clin Exp Immunol. 2018;195:15-24. https://doi. org/10.1111/cei.13223.

11. Steenblock C, Schwarz PEH, Ludwig B, Linkermann A, Zimmet P, Kulebyakin K, Tkachuk VA, Markov AG, Lehnert H, de Angelis MH, Rietzsch H, Rodionov RN, Khunti K, Hopkins D, Birkenfeld AL, Boehm B, Holt RIG, Skyler JS, DeVries JH, Renard E, Eckel RH, Alberti K, Geloneze B, Chan JC, Mbanya JC, Onyegbutulem HC, Ramachandran A, Basit A, Hassanein M, Bewick G, Spinas GA, Beuschlein F, Landgraf R, Rubino F, Mingrone G, Bornstein SR. COVID-19 and metabolic disease: mechanisms and clinical management. Lancet Diabetes Endocrinol. 2021;9:786-98. https://doi.org/10.1016/S2213-8587(21)00244-8.

12. Lotfaliany M, Bowe SJ, Kowal P, Orellana L, Berk M, Mohebbi M. Depression and chronic diseases: co-occurrence and communality of risk factors. J Affect Disord. 2018;241:461-8. https://doi.org/10.1016/j.jad.2018.08.011.

13. Saeedi P, Petersohn I, Salpea P, Malanda B, Karuranga S, Unwin N, Colagiuri S, Guariguata L, Motala AA, Ogurtsova K, Shaw JE, Bright D, Williams R, Committee IDFDA. Global and regional diabetes prevalence estimates for 2019 and projections for 2030 and 2045 : results from the International Diabetes Federation Diabetes Atlas, 9(th) edition. Diabetes Res Clin Pract. 2019;157: 107843. https://doi.org/10. 1016/j.diabres.2019.107843.

14. Pouwer F, Schram MT, Iversen MM, Nouwen A, Holt RIG. How 25 years of psychosocial research has contributed to a better understanding of the links between depression and diabetes. Diabet Med. 2020;37:383-92. https://doi.org/10.1111/dme.14227.

15. Abdel-Bakky MS, Amin E, Faris TM, Abdellatif AAH. Mental depression: relation to different disease status, newer treatments and its association with COVID-19 pandemic (review). Mol Med Rep. 2021. https://doi.org/10.3892/mmr.2021.12479.

16. Khaledi M, Haghighatdoost F, Feizi A, Aminorroaya A. The prevalence of comorbid depression in patients with type 2 diabetes: an updated systematic review and meta-analysis on huge number of observational studies. Acta Diabetol. 2019;56:631-50. https://doi.org/10.1007/ s00592-019-01295-9. 
17. Messina R, lommi M, Rucci P, Reno C, Fantini MP, Lunghi C, Altini M, Bravi F, Rosa S, Nicolucci A, Di Bartolo P. Is it time to consider depression as a major complication of type 2 diabetes? Evidence from a large population-based cohort study. Acta Diabetol. 2021. https://doi. org/10.1007/s00592-021-01791-x.

18. Roy T, Lloyd CE. Epidemiology of depression and diabetes: a systematic review. J Affect Disord. 2012;142(Suppl):S8-21. https://doi.org/ 10.1016/S0165-0327(12)70004-6.

19. Wang F, Wang S, Zong QQ, Zhang Q, Ng CH, Ungvari GS, Xiang YT. Prevalence of comorbid major depressive disorder in type 2 diabetes: a meta-analysis of comparative and epidemiological studies. Diabet Med. 2019;36:961-9. https://doi.org/10.1111/dme.14042.

20. Knol MJ, Twisk JW, Beekman AT, Heine RJ, Snoek FJ, Pouwer F. Depression as a risk factor for the onset of type 2 diabetes mellitus. A metaanalysis. Diabetologia. 2006;49:837-45. https://doi.org/10.1007/s00125-006-0159-x.

21. Rotella F, Mannucci E. Depression as a risk factor for diabetes: a meta-analysis of longitudinal studies. J Clin Psychiatry. $2013 ; 74: 31-7$. https://doi.org/10.4088/JCP.12r07922.

22. Nguyen MM, Perlman G, Kim N, Wu CY, Daher V, Zhou A, Mathers EH, Anita NZ, Lanctot KL, Herrmann N, Pakosh M, Swardfager W. Depression in type 2 diabetes: a systematic review and meta-analysis of blood inflammatory markers. Psychoneuroendocrinology. 2021;134: 105448. https://doi.org/10.1016/j.psyneuen.2021.105448.

23. Hoogendoorn CJ, Roy JF, Gonzalez JS. Shared dysregulation of homeostatic brain-body pathways in depression and type 2 diabetes. Curr Diabetes Rep. 2017;17:90. https://doi.org/10.1007/s11892-017-0923-y.

24. Berger I, Werdermann M, Bornstein SR, Steenblock C. The adrenal gland in stress-adaptation on a cellular level. J Steroid Biochem Mol Biol. 2019;190:198-206. https://doi.org/10.1016/j.jsbmb.2019.04.006.

25. McEwen BS. Allostasis and allostatic load: implications for neuropsychopharmacology. Neuropsychopharmacology. 2000;22:108-24. https://doi.org/10.1016/S0893-133X(99)00129-3.

26. Belvederi Murri M, Pariante C, Mondelli V, Masotti M, Atti AR, Mellacqua Z, Antonioli M, Ghio L, Menchetti M, Zanetidou S, Innamorati M, Amore M. HPA axis and aging in depression: systematic review and meta-analysis. Psychoneuroendocrinology. 2014;41:46-62. https://doi.org/10.1016/j.psyneuen.2013.12.004.

27. Stetler C, Miller GE. Depression and hypothalamic-pituitary-adrenal activation: a quantitative summary of four decades of research. Psychosom Med. 2011;73:114-26. https://doi.org/10.1097/PSY.0b013e31820ad12b.

28. Werdermann M, Berger I, Scriba LD, Santambrogio A, Schlinkert P, Brendel H, Morawietz H, Schedl A, Peitzsch M, King AJF, Andoniadou CL, Bornstein SR, Steenblock C. Insulin and obesity transform hypothalamic-pituitary-adrenal axis stemness and function in a hyperactive state. Mol Metab. 2021;43: 101112. https://doi.org/10.1016/j.molmet.2020.101112.

29. Bellass S, Lister J, Kitchen CEW, Kramer L, Alderson SL, Doran T, Gilbody S, Han L, Hewitt C, Holt RIG, Jacobs R, Prady SL, Shiers D, Siddiqi N, Taylor J. Living with diabetes alongside a severe mental illness: a qualitative exploration with people with severe mental illness, family members and healthcare staff. Diabet Med. 2021;38: e14562. https://doi.org/10.1111/dme.14562.

30. Simayi A, Mohemaiti P. Risk and protective factors of co-morbid depression in patients with type 2 diabetes mellitus: a meta analysis. Endocr J. 2019;66:793-805. https://doi.org/10.1507/endocrj.EJ18-0579.

31. Fung ACH, Tse G, Cheng HL, Lau ESH, Luk A, Ozaki R, So TTY, Wong RYM, Tsoh J, Chow E, Wing YK, Chan JCN, Kong APS. Depressive symptoms, co-morbidities, and glycemic control in Hong Kong Chinese elderly patients with type 2 diabetes mellitus. Front Endocrinol (Lausanne). 2018;9:261. https://doi.org/10.3389/fendo.2018.00261.

32. Boucher J, Kleinridders A, Kahn CR. Insulin receptor signaling in normal and insulin-resistant states. Cold Spring Harb Perspect Biol. 2014. https://doi.org/10.1101/cshperspect.a009191.

33. Esser N, Legrand-Poels S, Piette J, Scheen AJ, Paquot N. Inflammation as a link between obesity, metabolic syndrome and type 2 diabetes. Diabetes Res Clin Pract. 2014;105:141-50. https://doi.org/10.1016/j.diabres.2014.04.006.

34. Bornstein SR, Rubino F, Ludwig B, Rietzsch H, Schwarz PEH, Rodionov RN, Khunti K, Hopkins D, Birkenfeld AL, Boehm B, Amiel S, Holt RIG, Skyler JS, DeVries JH, Renard E, Eckel RH, Zimmet P, Alberti KG, Geloneze B, Chan JC, Mbanya JC, Onyegbutulem HC, Ramachandran A, Basit A, Hassanein M, Spinas GA, Beuschlein F, Mingrone G. Consequences of the COVID-19 pandemic for patients with metabolic diseases. Nat Metab. 2021;3:289-92. https://doi.org/10.1038/s42255-021-00358-y.

35. Gregory JM, Slaughter JC, Duffus SH, Smith TJ, LeStourgeon LM, Jaser SS, McCoy AB, Luther JM, Giovannetti ER, Boeder S, Pettus JH, Moore DJ. COVID-19 severity is tripled in the diabetes community: a prospective analysis of the pandemic's impact in type 1 and type 2 diabetes. Diabetes Care. 2021;44:526-32. https://doi.org/10.2337/dc20-2260.

36. Khunti K, Del Prato S, Mathieu C, Kahn SE, Gabbay RA, Buse JB. COVID-19, hyperglycemia, and new-onset diabetes. Diabetes Care. 2021;44:2645-55. https://doi.org/10.2337/dc21-1318.

37. Alsadhan I, Alruwashid S, Alhamad M, Alajmi S, Alshehri S, Alfadhli E, Ekhzaimy A. Diabetic ketoacidosis precipitated by coronavirus disease 2019 infection: case series. Curr Ther Res Clin Exp. 2020;93: 100609. https://doi.org/10.1016/j.curtheres.2020.100609.

38. Heaney Al, Griffin GD, Simon EL. Newly diagnosed diabetes and diabetic ketoacidosis precipitated by COVID-19 infection. Am J Emerg Med. 2020;38:2491e3-4. https://doi.org/10.1016/j.ajem.2020.05.114.

39. Hollstein T, Schulte DM, Schulz J, Gluck A, Ziegler AG, Bonifacio E, Wendorff M, Franke A, Schreiber S, Bornstein SR, Laudes M. Autoantibody-negative insulin-dependent diabetes mellitus after SARS-CoV-2 infection: a case report. Nat Metab. 2020;2:1021-4. https://doi.org/10.1038/s42255-020-00281-8.

40. Li J, Wang X, Chen J, Zuo X, Zhang H, Deng A. COVID-19 infection may cause ketosis and ketoacidosis. Diabetes Obes Metab. 2020;22:1935-41. https://doi.org/10.1111/dom.14057.

41. Montefusco L, Ben Nasr M, D'Addio F, Loretelli C, Rossi A, Pastore I, Daniele G, Abdelsalam A, Maestroni A, Dell'Acqua M, Ippolito E, Assi E, Usuelli V, Seelam AJ, Fiorina RM, Chebat E, Morpurgo P, Lunati ME, Bolla AM, Finzi G, Abdi R, Bonventre JV, Rusconi S, Riva A, Corradi D, Santus P, Nebuloni M, Folli F, Zuccotti GV, Galli M, Fiorina P. Acute and long-term disruption of glycometabolic control after SARS-CoV-2 infection. Nat Metab. 2021;3:774-85. https://doi.org/10.1038/s42255-021-00407-6.

42. Naguib MN, Raymond JK, Vidmar AP. New onset diabetes with diabetic ketoacidosis in a child with multisystem inflammatory syndrome due to COVID-19. J Pediatr Endocrinol Metab. 2021;34:147-50. https://doi.org/10.1515/.jpem-2020-0426. 
43. Rubino F, Amiel SA, Zimmet P, Alberti G, Bornstein S, Eckel RH, Mingrone G, Boehm B, Cooper ME, Chai Z, Del Prato S, Ji L, Hopkins D, Herman WH, Khunti K, Mbanya JC, Renard E. New-onset diabetes in covid-19. N Engl J Med. 2020;383:789-90. https://doi.org/10. 1056/NEJMc2018688.

44. Laurenzi A, Caretto A, Molinari C, Mercalli A, Melzi R, Nano R, Tresoldi C, Rovere Querini P, Ciceri F, Lampasona V, Bosi E, Scavini M, Piemonti L. No evidence of long-term disruption of glycometabolic control after SARS-CoV-2 infection. J Clin Endocrinol Metab. 2021. https://doi.org/10.1210/clinem/dgab792.

45. Muller JA, Gross R, Conzelmann C, Kruger J, Merle U, Steinhart J, Weil T, Koepke L, Bozzo CP, Read C, Fois G, Eiseler T, Gehrmann J, van Vuuren J, Wessbecher IM, Frick M, Costa IG, Breunig M, Gruner B, Peters L, Schuster M, Liebau S, Seufferlein T, Stenger S, Stenzinger A, MacDonald PE, Kirchhoff F, Sparrer KMJ, Walther P, Lickert H, Barth TFE, Wagner M, Munch J, Heller S, Kleger A. SARS-CoV-2 infects and replicates in cells of the human endocrine and exocrine pancreas. Nat Metab. 2021;3:149-65. https://doi.org/10.1038/ s42255-021-00347-1.

46. Steenblock C, Richter S, Berger I, Barovic M, Schmid J, Schubert U, Jarzebska N, von Massenhausen A, Linkermann A, Schurmann A, Pablik J, Dienemann T, Evert K, Rodionov RN, Semenova NY, Zinserling VA, Gainetdinov RR, Baretton G, Lindemann D, Solimena M, Ludwig B, Bornstein SR. Viral infiltration of pancreatic islets in patients with COVID-19. Nat Commun. 2021;12:3534. https://doi.org/ 10.1038/s41467-021-23886-3.

47. Wu CT, Lidsky PV, Xiao Y, Lee IT, Cheng R, Nakayama T, Jiang S, Demeter J, Bevacqua RJ, Chang CA, Whitener RL, Stalder AK, Zhu B, Chen H, Goltsev Y, Tzankov A, Nayak JV, Nolan GP, Matter MS, Andino R, Jackson PK. SARS-CoV-2 infects human pancreatic beta cells and elicits beta cell impairment. Cell Metab. 2021. https://doi.org/10.1016/j.cmet.2021.05.013.

48. Zinserling VA, Bornstein SR, Narkevich TA, Sukhanova YV, Semenova NY, Vashukova MA, Steenblock C. Stillborn child with diffuse SARS-CoV-2 viral infection of multiple organs. IDCases. 2021;26: e01328. https://doi.org/10.1016/j.idcr.2021.e01328.

49. Wostyn P. COVID-19 and chronic fatigue syndrome: is the worst yet to come? Med Hypotheses. 2021;146: 110469. https://doi.org/ 10.1016/j.mehy.2020.110469.

50. Ramakrishnan RK, Kashour T, Hamid Q, Halwani R, Tleyjeh IM. Unraveling the mystery surrounding post-acute sequelae of COVID-19. Front Immunol. 2021;12: 686029. https://doi.org/10.3389/fimmu.2021.686029.

51. Maestre-Muniz MM, Arias A, Mata-Vazquez E, Martin-Toledano M, Lopez-Larramona G, Ruiz-Chicote AM, Nieto-Sandoval B, Lucendo AJ. Long-term outcomes of patients with coronavirus disease 2019 at one year after hospital discharge. J Clin Med. 2021. https://doi. org/10.3390/jcm10132945.

52. Brosh-Nissimov T, Orenbuch-Harroch E, Chowers M, Elbaz M, Nesher L, Stein M, Maor Y, Cohen R, Hussein K, Weinberger M, Zimhony O, Chazan B, Najjar R, Zayyad H, Rahav G, Wiener-Well Y. BNT162b2 vaccine breakthrough: clinical characteristics of 152 fully vaccinated hospitalized COVID-19 patients in Israel. Clin Microbiol Infect. 2021. https://doi.org/10.1016/j.cmi.2021.06.036.

53. Ornell F, Schuch JB, Sordi AO, Kessler FHP. "Pandemic fear" and COVID-19: mental health burden and strategies. Braz J Psychiatry. 2020;42:232-5. https://doi.org/10.1590/1516-4446-2020-0008.

54. Steenblock C, Todorov V, Kanczkowski W, Eisenhofer G, Schedl A, Wong ML, Licinio J, Bauer M, Young AH, Gainetdinov RR, Bornstein SR. Severe acute respiratory syndrome coronavirus 2 (SARS-CoV-2) and the neuroendocrine stress axis. Mol Psychiatry. 2020;25:1611-7. https://doi.org/10.1038/s41380-020-0758-9.

55. Cena H, Fiechtner L, Vincenti A, Magenes VC, De Giuseppe R, Manuelli M, Zuccotti GV, Calcaterra V. COVID-19 pandemic as risk factors for excessive weight gain in pediatrics: the role of changes in nutrition behavior. A narrative review. Nutrients. 2021. https://doi.org/ 10.3390/nu13124255.

56. Dun Y, Ripley-Gonzalez JW, Zhou N, You B, Li Q, Li H, Zhang W, Thomas RJ, Olson TP, Liu J, Dong Y, Liu S. Weight gain in Chinese youth during a 4-month COVID-19 lockdown: a retrospective observational study. BMJ Open. 2021;11: e052451. https://doi.org/10.1136/ bmjopen-2021-052451.

57. Kang HM, Jeong DC, Suh BK, Ahn MB. The impact of the coronavirus disease-2019 pandemic on childhood obesity and vitamin D status. J Korean Med Sci. 2021;36: e21. https://doi.org/10.3346/jkms.2021.36.e21.

58. Gilsbach S, Herpertz-Dahlmann B, Konrad K. Psychological impact of the COVID-19 pandemic on children and adolescents with and without mental disorders. Front Public Health. 2021;9: 679041. https://doi.org/10.3389/fpubh.2021.679041.

59. Ocampo Gonzalez AA, Castillo Garcia JF, Pabon Sandoval LC, Tovar Cuevas JR, Hidalgo Ibarra SA, Calle Sandoval DA, Cortes Gonzalez E, Garcia Chica KS, Pabon Lozano JS, Munoz Rico MDC. Depressive symptomatology in adults during the COVID-19 pandemic. J Investig Med. 2021. https://doi.org/10.1136/jim-2021-001992.

60. Werner AM, Tibubos AN, Mulder LM, Reichel JL, Schafer M, Heller S, Pfirrmann D, Edelmann D, Dietz P, Rigotti T, Beutel ME. The impact of lockdown stress and loneliness during the COVID-19 pandemic on mental health among university students in Germany. Sci Rep. 2021;11:22637. https://doi.org/10.1038/s41598-021-02024-5.

61. Jin Y, Sun T, Zheng P, An J. Mass quarantine and mental health during COVID-19: a meta-analysis. J Affect Disord. 2021;295:1335-46. https://doi.org/10.1016/j.jad.2021.08.067.

62. Docherty S, Haskell-Ramsay CF, McInnes L, Wetherell MA. The effects of COVID-19 lockdown on health and psychosocial functioning in older adults aged 70 and over. Gerontol Geriatr Med. 2021;7:23337214211039976. https://doi.org/10.1177/23337214211039974.

63. Prekazi L, Hajrullahu V, Bahtiri S, Kryeziu B, Hyseni B, Taganoviq B, Gallopeni F. The impact of coping skills in post-traumatic growth of healthcare providers: when mental health is deteriorating due to COVID-19 pandemic. Front Psychol. 2021. https://doi.org/10. 3389/fpsyg.2021.791568.

64. Bulkes NZ, Davis K, Kay B, Riemann BC. Comparing efficacy of telehealth to in-person mental health care in intensive-treatmentseeking adults. J Psychiatr Res. 2021. https://doi.org/10.1016/j.jpsychires.2021.11.003.

65. Rogers JP, Chesney E, Oliver D, Pollak TA, McGuire P, Fusar-Poli P, Zandi MS, Lewis G, David AS. Psychiatric and neuropsychiatric presentations associated with severe coronavirus infections: a systematic review and meta-analysis with comparison to the COVID-19 pandemic. Lancet Psychiatry. 2020;7:611-27. https://doi.org/10.1016/S2215-0366(20)30203-0.

66. Liu J, Li S, Liu J, Liang B, Wang X, Wang H, Li W, Tong Q, Yi J, Zhao L, Xiong L, Guo C, Tian J, Luo J, Yao J, Pang R, Shen H, Peng C, Liu T, Zhang Q, Wu J, Xu L, Lu S, Wang B, Weng Z, Han C, Zhu H, Zhou R, Zhou H, Chen X, Ye P, Zhu B, Wang L, Zhou W, He S, He Y, Jie S, Wei P, Zhang J, Lu Y, Wang W, Zhang L, Li L, Zhou F, Wang J, Dittmer U, Lu M, Hu Y, Yang D, Zheng X. Longitudinal characteristics of 
lymphocyte responses and cytokine profiles in the peripheral blood of SARS-CoV-2 infected patients. EBioMedicine. 2020;55: 102763. https://doi.org/10.1016/j.ebiom.2020.102763.

67. Bourmistrova NW, Solomon T, Braude P, Strawbridge R, Carter B. Long-term effects of COVID-19 on mental health: a systematic review. J Affect Disord. 2021;299:118-25. https://doi.org/10.1016/j.jad.2021.11.031.

68. Dotan A, Shoenfeld Y. Post-COVID syndrome: the aftershock of SARS-CoV-2. Int J Infect Dis. 2021;114:233-5. https://doi.org/10.1016/j. ijid.2021.11.020.

69. Splinter MJ, Velek P, Ikram MK, Kieboom BCT, Peeters RP, Bindels PJE, Ikram MA, Wolters FJ, Leening MJG, de Schepper EIT, Licher S. Prevalence and determinants of healthcare avoidance during the COVID-19 pandemic: a population-based cross-sectional study. PLoS Med. 2021;18: e1003854. https://doi.org/10.1371/journal.pmed.1003854.

70. Alessi J, de Oliveira GB, Franco DW, Brino do Amaral B, Becker AS, Knijnik CP, Kobe GL, de Carvalho TR, Telo GH, Schaan BD, Telo GH. Mental health in the era of COVID-19: prevalence of psychiatric disorders in a cohort of patients with type 1 and type 2 diabetes during the social distancing. Diabetol Metab Syndr. 2020;12:76. https://doi.org/10.1186/s13098-020-00584-6.

71. Alessi J, Scherer G, Erthal IN, Teixeira JB, de Oliveira GB, Jaeger EH, de Carvalho TR, Schaan BD, Telo GH. One in ten patients with diabetes have suicidal thoughts after 1 year of the COVID-19 pandemic: we need to talk about diabetes and mental health not only during suicide prevention awareness month. Acta Diabetol. 2021. https://doi.org/10.1007/s00592-021-01807-6.

72. Al-Sofiani ME, Albunyan S, Alguwaihes AM, Kalyani RR, Golden SH, Alfadda A. Determinants of mental health outcomes among people with and without diabetes during the COVID-19 outbreak in the Arab Gulf Region. J Diabetes. 2021;13:339-52. https://doi.org/10.1111/ 1753-0407.13149.

73. Moradian S, Teufel M, Jahre L, Musche V, Fink M, Dinse H, Schweda A, Weismuller B, Dorrie N, Tan S, Skoda EM, Bauerle A. Mental health burden of patients with diabetes before and after the initial outbreak of COVID-19: predictors of mental health impairment. BMC Public Health. 2021;21:2068. https://doi.org/10.1186/s12889-021-12101-z.

74. Sankar P, Ahmed WN, Mariam Koshy V, Jacob R, Sasidharan S. Effects of COVID-19 lockdown on type 2 diabetes, lifestyle and psychosocial health: a hospital-based cross-sectional survey from South India. Diabetes Metab Syndr. 2020;14:1815-9. https://doi.org/10.1016/j.dsx. 2020.09.005.

75. Alessi J, de Oliveira GB, Franco DW, Becker AS, Knijnik CP, Kobe GL, Amaral BB, de Brito A, Schaan BD, Telo GH. Telehealth strategy to mitigate the negative psychological impact of the COVID-19 pandemic on type 2 diabetes: a randomized controlled trial. Acta Diabetol. 2021;58:899-909. https://doi.org/10.1007/s00592-021-01690-1.

76. Quinn LM, Davies MJ, Northern A, Brough C, Schreder S, Stribling B, Khunti K, Hadjiconstantinou M. Use of MyDesmond digital education programme to support self-management in people with type 2 diabetes during the COVID-19 pandemic. Diabet Med. 2021;38: e14469. https://doi.org/10.1111/dme.14469.

77. Morens DM, Fauci AS. Emerging infectious diseases: threats to human health and global stability. PLoS Pathog. 2013;9: e1003467. https:// doi.org/10.1371/journal.ppat.1003467.

78. Tucci V, Moukaddam N, Meadows J, Shah S, Galwankar SC, Kapur GB. The forgotten plague: psychiatric manifestations of ebola, zika, and emerging infectious diseases. J Glob Infect Dis. 2017;9:151-6. https://doi.org/10.4103/jgid.jgid_66_17.

79. Ai X, Yang J, Lin Z, Wan X. Mental health and the role of physical activity during the COVID-19 pandemic. Front Psychol. 2021;12: 759987. https://doi.org/10.3389/fpsyg.2021.759987.

80. Metoki $\mathrm{H}$. The significance of observing the risk of non-communicable diseases after large-scale disasters and communicable disease epidemics. JMA J. 2021;4:305-10. https://doi.org/10.31662/jmaj.2021-0126.

81. DeJean D, Giacomini M, Vanstone M, Brundisini F. Patient experiences of depression and anxiety with chronic disease: a systematic review and qualitative meta-synthesis. Ont Health Technol Assess Ser. 2013;13:1-33.

82. Gask L, Macdonald W, Bower P. What is the relationship between diabetes and depression? A qualitative meta-synthesis of patient experience of co-morbidity. Chronic Illn. 2011;7:239-52. https://doi.org/10.1177/1742395311403636.

Publisher's Note Springer Nature remains neutral with regard to jurisdictional claims in published maps and institutional affiliations. 